\title{
Computer Chess at IFIP 80
}

Rodney Topor

Monash University, Australia

An exhibition of computer chess programs was held in Melbourne, Australia from October 14 to October 19 in conjunction with the second week of IFIP 80, the 8 th World Computer Congress and Exhibition. Most of the time, visitors were able to play informal games against programs, but each afternoon an exhibition game was held between the best available program and a top Australian player, and one evening an exhibition game was played between the best two programs. The exhibition attracted a great deal of interest and was generally considered to have been very successful.

The programs exhibited were:

- 2 copies of Sargon II running on Apple II computers

- Sargon 2.5

- 2 copies of CHESS 4.7 running on a Cyber 173

- DUCHESS running on an IBM 3032.

The Cyber 173 was the largest CDC machine available during the day, and as it appears to be 15 times slower than the Cyber 176, CHESS 4.7 was severely handicapped. DUCHESS was available only part of the time. Thus, although the full abilities of modern programs were not displayed, they were obviously far stronger than the Chess Challengers, etc., which were the only chess programs that many visitors had seen previously. Sargon 2.5's electronic board was of special interest.

The top Australianplayers won every one of the exhibition games played. Robert Jamieson, Gary West, and other members of Australia's Olympic team also demolished CHESS 4.7 and DUCHESS repeatedly at blitz chess. Ian Rogers, the current Australian champion, played two games blindfold against DUCHESS (set to average $60 \mathrm{cPU}$ seconds per move) and won both of them easily. (The computer operators unfortunately managed to destroy the file containing the scores of these games.) The only success any of the programs (nearly) had was when CHESS 4.7 achieved a won position against Mike Woodhams, a former Victorian champion, only to be trapped in a mating net. The unannotated score of this game appears below. Thus, although casual chess players left the exhibition impressed, stronger players retained their conviction that chess programmers still had a long way to go.

I would like to thank Ben Mittman, Dan and Kathe Spracklen, Bruce Wright, John Englander, The Australian Road Research Board, Control Data, IBM, and Shell Australia for their help in making this exhibition possible. 


\section{Computer Chess at IFIP 80}

(continued from page 10)

CHESS 4.7 Game Score 80/10/15. 17.04.01.

Mike Woodhams

White

1. $\mathrm{P}-\mathrm{Q} 4$

2. $\mathrm{P}-\mathrm{QB} 4$

3. $\mathrm{N}-\mathrm{KB} 3$

4. $\mathrm{P}-\mathrm{Q} 5$

5. $\mathrm{P}-\mathrm{K} 4$

6. $\mathrm{N}-\mathrm{B} 3$

7. $\mathrm{B}-\mathrm{N} 5$

8. $P * P$

9. $\mathrm{N}-\mathrm{K} 5$

10. Q-R4 check

11. $\mathrm{N} * \mathrm{~B}$

12. $\mathrm{P}-\mathrm{QN} 4$

13. $\mathrm{P} * \mathrm{P}$

14. $\mathrm{R}-\mathrm{QN} 1$

15. $\mathrm{Q}-\mathrm{Q} 4$

16. B-N5

17. $Q * \mathrm{~N}$

18. $\mathrm{Q}-\mathrm{K} 3$

19. B-B4

20. $\mathrm{K}-\mathrm{Q} 2$

21. $\mathrm{R} * \mathrm{P}$

22. $\mathrm{R}-\mathrm{N} 1$

23. $R * P$

24. $\mathrm{P}-\mathrm{Q} 6$

25. $\mathrm{K}-\mathrm{B} 2$

26. $\mathrm{R}-\mathrm{B} 7$

27. K-B1

28. $\mathrm{N}-\mathrm{Q} 1$

29. $\mathrm{K}-\mathrm{N} 2$

30. N-B3

31. $\mathrm{K}-\mathrm{B} 2$

32. $\mathrm{Q}-\mathrm{K} 6$

33. $\mathrm{R} * \mathrm{P}$ check

34. $Q * B$ checkmate

20 seconds per move
CDC Cyber 173

Black

$\mathrm{P}-\mathrm{Q} 4$

$\mathrm{P} * \mathrm{P}$

N-QB3

$\mathrm{N}-\mathrm{R} 4$

$\mathrm{P}-\mathrm{QB} 3$

$\mathrm{N}-\mathrm{B} 3$

$\mathrm{P} * \mathrm{P}$

B-B4

$\mathrm{Q}-\mathrm{N} 3$

$\mathrm{B}-\mathrm{Q} 2$

$\mathrm{N} * \mathrm{~N}$

$\mathrm{P} * \mathrm{P}$ ep

$\mathrm{N} * \mathrm{P}$

$\mathrm{N}-\mathrm{B} 4$

$\mathrm{Q}-\mathrm{N} 3$

$\mathrm{P}-\mathrm{QR} 3$

$\mathrm{P} * \mathrm{~B}$

P-R3

$Q * P$

$\mathrm{P}-\mathrm{N} 5$

$Q * R$

Q-N7

Q-B8

R-R8

Q-B5

R-R7 check

Q-B8 check

R-R8 check

Q-R3

Q-R6 check

$\mathrm{P}-\mathrm{B} 4$

$\mathrm{N}-\mathrm{N} 3$

$B * \mathbf{R}$ 